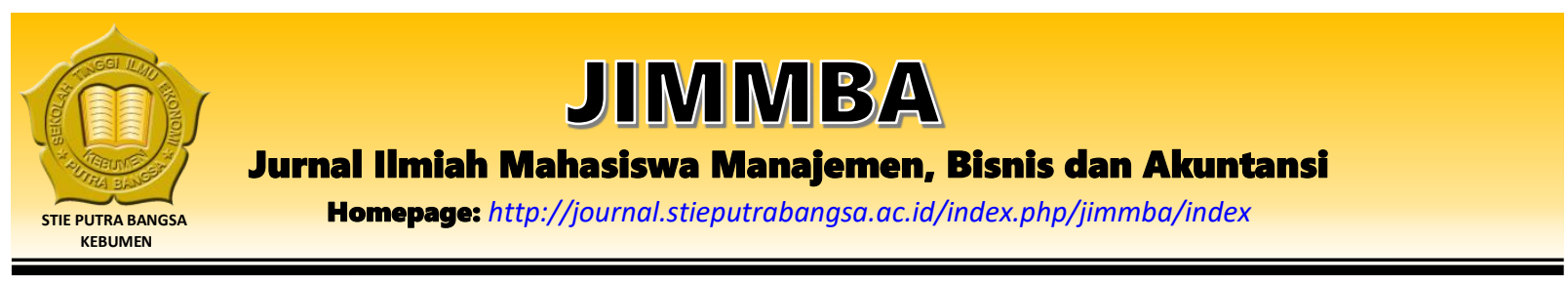

\title{
Pengaruh Tax Avoidance Terhadap Struktur Modal dengan Variabel Mediasi Ukuran Perusahaan
}

\author{
Ellen Simbolon ${ }^{1}$, Francis Hutabarat ${ }^{2}$ \\ 1,2 Universitas Advent Indonesia \\ Email: simbolonellen15@gmail.com¹, fmhutabarat@unai.edu²
}

\begin{tabular}{l}
\multicolumn{1}{c}{ ARTICLE INFO } \\
\hline Article History: \\
Received: August $28^{\text {th }} 2020$ \\
Accepted: September $21^{\text {st }}$ \\
2020 \\
Published: October 21 $1^{\text {st }} 2020$ \\
Keywords: Tax Avoidance, \\
Struktur Modal, Ukuran \\
Perusahaan
\end{tabular}

\section{Pendahuluan}

Setiap instansi baik perseroan maupun korporasi membutuhkan modal untuk mengembangkan usahanya, baik modal asing ataupun modal sendiri. Pendapat Munawir (2001) tentang modal adalah kepemilikan oleh suatu perusahaan baik itu dalam modal saham atau pos modal, dana yang tersisa setelah melunasi atau menyelesaikan kewajibannya. Perbandingan antara kewajiban (hutang) dengan ekuitas disebut sebagai struktur modal. Struktur modal sangat dipengaruhi beberapa faktor yaitu konsekuensi yang mungkin terjadi pada perusahaan, beban pajak, keefektifan keuangan dan kegigihan manajemen. Dalam hal ini khususnya dalam hal utang manajer setiap perusahaan harus mampu menyeimbangkan modal asing dan modal sendiri. Hutang (modal asing) sudah merupakan hal umum yang sering kita dengarkan. Hutang (modal asing) merupakan salah satu pendanaan yang dilakukan oleh perusahaan.

Kasus utang tertinggi berdasarkan laporan keuangan 2019 yang sudah dibedah pada perusahaan subsektor tekstil adalah PT Century Textile Industry Tbk (CNTX) senilai US\$47.8 juta dengan rasio hutang 5.70. Kasus yang lain terjadi pada PT Garuda Indonesia (Persero) Tbk memiliki utang sebesar US\$1.63 juta tetapi mengingat dana yang ada tidak cukup untuk membayar utang yang jatuh tempo tahun depan sehingga berusaha mencari dana tambahan sebesar US\$900 juta. 
Beberapa faktor yang menjadi penyebab terbentuknya struktur modal adalah penghindaran pajak dan ukuran perusahaan. Penghindaran pajak oleh wajib pajak baik secara ilegal maupun legal, melihat adanya peluang yang memungkinkan untuk melakukan Tax Avoidance (penghindaran pajak). Menurut Pohan (2016), mengatakan bahwa tax avoidance merupakan suatu cara yang dilakukan untuk menghindari pembayaran pajak dengan menaati ketentuan pajak tetapi menggunakan cara yang lain seperti memanfaatkan kelemahan-kelemahan yang ada dalam ketentuan perpajakan oleh si wajib pajak. Sehingga dapat kita katakan bahwa Tax avoidance merupakan suatu cara penghindaran pajak dengan pemanfaatan terhadap celah peraturan pajak yang ada. Cara ini memang legal tetapi tidak sesuai dengan norma yang ada. Dalam hal ini Wedari (2006) dalam Eka (2010) mengatakan ukuran dari sebuah perusahaan dapat dilihat dari kapitalisasi pasar, nilai buku dan laba nya, pada perusahaan besar hal itu dapat dilihat melalui peningkatannya.

Menurut Wardani dan Rumahorbo (2018), dalam hasil penelitiannya bahwa tax avoidance pada biaya hutang tidak berpengaruh. Sedangkan penelitian Elvis dan Desy (2019), menyatakan bahwa tax avoidance memiliki pengaruh yang negatif pada biaya hutang. Sedangkan penelitian terdahulu mengenai ukuran perusahaan dan struktur modal menurut Sawitri dan Lestari (2015) berpengaruh positif tetapi tidak relevan. Sama halnya dengan penelitian menurut Septiani dan Suryana (2018) terbukti berpengaruh. Artinya apabila size mengalami peningkatan maka struktur modal mengalami peningkatan pula. Berdasarkan penelitian terdahulu dengan hasil penelitian yang berbeda, maka peneliti ingin membuktikan penelitian sebelumnya dengan menggabungkan variabel penghindaran pajak dan ukuran perusahaan atas subsektor makanan \& minuman yang listing di BEI periode 2018-2019.

\section{Kajian Teori dan Telaah Literatur}

\section{Tax Avoidance}

Penghindaran pajak merupakan suatu cara pengurangan pajak oleh perusahaan. Arfan (2016:51) dalam Wardani dan Rumahorbo (2018) mengemukakan rumus sebagai berikut :

$$
C E T R=\frac{\text { Pembayaran Pajak }}{\text { Laba Sebelum Pajak }}
$$

\section{Struktur Modal}

Pengukuran dalam penelitian ini adalah banyaknya kewajiban dengan ekuitas, dengan rumus sebagai berikut.

$$
D E R=\frac{\text { Total Hutang }}{\text { Total Modal }}
$$

\section{Ukuran Perusahaan}

Peneliti mengambil total aset sebagai indikator, dengan rumus :

$$
\text { Firm size }=\operatorname{Logn}(\text { Total Assets })
$$

\section{Tax Avoidance dan Struktur Modal}


Menurut Pohan (2016) dalam penelitiannya mengatakan bahwa penghindaran pajak (tax avoidance) itu sendiri yaitu trik yang digunakan perusahaan untuk melakukan penghindaran pajak secara legal dan sesuai dengan peraturan perpajakan. Tidak jarang kita dikagetkan oleh pemberitaan mengenai hal penghindaran pajak oleh perusahaan. Padahal pada kenyataannya perusahaan ialah wajib pajak yang memiliki kontribusi yang lebih daripada wajib pajak lainnya. Astuti dan Aryani (2016) menyatakan bahwa bagi perusahaan, mengupayakan agar membayar pajak sekecil mungkin sehingga mendapatkan laba bersih yang lebih besar. Rudi dan Dwimulyani (2019), penghindaran pajak pada struktur modal tidak memiliki pengaruh yang signifikan. Sedangkan Elvis \& Desy (2019), Penghindaran pajak memberikan pengaruh yang negatif pada biaya hutang. Dengan arti bahwa jika terjadi peningkatan nilai Cash ETR maka menyatakan penurunan peghindaran pajak perusahaan dan biaya hutang yang terjadi menurun pula. Maka dalam melakukan perbandingan digunakanlah Cash ETR sebagai indikator karena jumlah kas yang dibayarkan oleh perusahaan dapat menunjukkan tindakan penghindaran pajak, diakibatkan oleh banyaknya kas keluar oleh perusahaan dalam melunasi pajak ialah beban pajak yang sudah dibayar.

\section{H1 : Penghindaran Pajak dan Struktur Modal berpengaruh positif dan signifikan}

\section{Ukuran Perusahaan dan Struktur Modal}

Baik buruknya kinerja perusahaan boleh diketahui dengan melihat tingkat ukuran perusahaan. Ambarsari \& Hermanto (2017) dalam penelitiannya menyimpulkan ukuran perusahaan tidak berhubungan pada struktur modal . Sedangkan Lasut, Rante \& Raintung (2018), pada penelitian yang dilakukannya terbukti adanya pengaruh yang positif dan relevan. Sama halnya dengan penelitian Denziana \& Yunggo (2017), menjelaskan pengaruh ukuran perusahaan dan struktur modal berpengaruh signifikan dan positif.

\section{H2 : Ukuran Perusahaan dan Struktur Modal berpengaruh positif dan signifikan}

\section{Metode Penelitian}

\section{Variabel Penelitian}

Komponen varibel independend (X) yaitu Tax Avoidance dengan indikator Cash ETR (CETR). Adapun variabel mediasi yaitu Ukuran Perusahaan, sedangkan variabel dependend (Y) yaitu Struktur Modal dengan indikatornya DER.

\section{Populasi E Sampel}

Perusahaan subsektor makanan dan minuman yang Terdaftar di BEI tahun 2018-2019 dari 15 perusahaan dan 30 sampel. Adapun nama perusahaan dan kode perusahaan yakni:

\begin{tabular}{clc}
\hline No. & \multicolumn{1}{c}{ Nama Perusahaan } & Kode Perusahaan \\
\hline 1. & PT Wilmar Cahaya Indonesia Tbk & CEKA \\
2. & PT Campina Ice Cream Industry Tbk & CAMP \\
3. & Tiga Pilar Sejahtera Food Tbk & AISA \\
4. & Ultra Jaya Milk Industry Tbk & ULTJ \\
5. & PT Siantar Top Tbk & STTP \\
6. & PT Sariguna Primatirta Tbk & CLEO \\
7. & PT Buyung Poetra Sembada Tbk & HOKI \\
8. & Delta Djakarta Tbk & DLTA \\
9. & Indofood Sukses Makmur Tbk & INDF
\end{tabular}


10. Indofood CBP Sukses Makmur Tbk ICBP

11. Mayora Indah Tbk MYOR

12. Multi Bintang Indonesia Tbk MLBI

13. PT Prima Cakrawala Abadi Tbk PCAR

14. Prasidha Aneka Niaga Tbk PSDN

15. PT Nippon Indosari Corpindo Tbk ROTI

\section{Sumber Data}

Data yang digunakan dari perusahaan subsektor makanan dan minuman yang listing di BEI periode 2018-2019.

\section{Analisis Data}

Analisis statistik data yang digunakan yaitu koefisien determinasi ,signifikan test, regresi analisis. Dengan persamaan sebagai berikut.

$$
\text { DER }=\text { b0 + b1CETR + b2Ln TA }
$$

Deskripsi :

DER : Debt to Equity Ratio, Struktur Modal

b0 : konstan

b1, b2 : koefisien

CETR : Cash Effective Tax Rate, Tax Avoidance

Ln TA : Logaritma natural Total Asset, Ukuran Perusahaan

\section{Hasil dan Pembahasan}

\section{Koefisien Determinasi}

Tabel SPSS menunjukkan bahwa pada model 1 nilai R-Squarenya sebanyak .041 yang artinya kontribusi penghidaran pajak terhadap perbedaan pada struktur modal adalah sebesar $4.1 \%$. Terkait model 2, didapati bahwa dengan mediasi ukuran perusahaan maka didapati kontribusi penghidaran pajak dan ukuran perusahaan terhadap perubahan pada struktur modal menjadi sebesar $19.5 \%$ dan didapati perubahan dalam nilai R-Square change sebesar .135 atau $13.5 \%$.

\section{Significant Test}

Hasil uji signifikan menunjukkan bahwa pada model 1 penghidaran pajak dan struktur modal tidak berpengaruh, ini dibuktikan dengan F-test 1.203 dan nilai significant 0.282 pada $\alpha=0.05$ atau 5\%. Sedangkan pada model 2, didapati bahwa dengan adanya mediasi ukuran perusahaan maka didapati pengaruh penghidaran pajak, ukuran perusahaan terhadap struktur modal adalah significant dengan tingkat signifikan 0.054 pada level significant $10 \%$ dengan F-test 3.260.

\section{Regression}


Hasil uji signifikan menunjukkan bahwa pada variable independent terlihat bahwa pada model 1 tidak ada pengaruh signifikan pada variable penghidaran pajak terhadap struktur modal dengan nilai signifikan 0.282 pada level signifikan 5\%. Sedangkan pada model 2, didapati dengan adanya mediasi ukuran perusahaan, didapati bahwa penghidaran pajak dan struktur modal tetap memiliki pengaruh yang tidak signifikan yaitu 0.189 pada level signifikan 5\%. Dan terkait ukuran perusahaan dan struktur modal didapati adanya pengaruh yang signifikan dengan level signifikan 0.032 pada level signifikan $5 \%$. Dengan demikian keberadaan ukuran perusahaan sepenuhnya memediasi pengaruh penghidaran pajak dan struktur modal.

\section{H1 : Tax Avoidance dan Struktur Modal}

Hasil penelitian membuktikan bahwa penghindaran pajak (ETR) dan struktur modal tidak berpengaruh, sehingga $\mathrm{H}_{1}$ ditolak. Hasil ini didukung oleh Wardani dan Rumahorbo (2018), sebagai peneliti terdahulu bahwa dalam penelitiannya menyatakan tax avoidance tidak berpengaruh terhadap struktur modal sedangkan Elvis \& Desy (2019) tidak mendukung hasil ini karena dalam penelitiannya menunjukkan bahwa tax aoidance berpegaruh negatif terhadap stuktur modal.

\section{H2 : Ukuran Perusahaan dan Profitabilitas}

Hasil penelitian membuktikan yakni ukuran perusahaan dan struktur modal berpengaruh signifikan, sehingga H2 diterima. Sama seperti penelitian yang dilakukan oleh Denziana dan Yunggo (2017) dan juga Lasut, Rante \& Raintung (2018). Akan tetapi bertentangan dengan hasil penelitian Ambarsari dan Hermanto (2017) yang menunjukkan tidak ada pengaruh antar keduanya.

\section{Penutup}

\section{Simpulan}

Dari penjelasan yang sudah diuraikan di atas diperoleh simpulan bahwa :

1. Tax Avoidance dan Struktur Modal tidak berpengaruh signifikan pada perusahaan subsektor makanan dan minuman yang terdaftar di BEI tahun 2018-2019.

2. Ukuran Perusahaan dan Struktur Modal berpengaruh signifikan pada perusahaan subsektor makanan dan minuman yang terdaftar di BEI tahun 2018-2019.

\section{Saran}

Saran yang bisa disampaikan ialah bagi manajemen perusahaan kiranya setelah membaca hasil penelitian ini boleh mengetahui bahwa penghindaran pajak dan struktur modal tidak berpengaruh berbanding terbalik dengan adanya pengaruh relevan dan positif antar ukuran perusahaan \& struktur modal. Apabila penelitian ini benar adanya, maka perusahaan dapat mengetahui alasan yang mempengaruhi struktur modal dan perusahaan boleh berjalan dengan sebaik-baiknya. Bagi investor agar boleh memasukkan ukuran perusahaan sebagai tolak ukur sebelum melakukan penanaman modal pada perusahaan yang dituju tersebut. Bagi peneliti berikutnya agar mengambil sampel yang lain selain perusahaan subsektor diatas.

\section{Referensi}


Afandi, C. D. F., \& Riharjo, I. B. (2017). Pengaruh Intellectual Capital Terhadap Kinerja Perusahaan Yang Terdaftar Di Bursa Efek Indonesia. Jurnal Ilmu dan Riset Akuntansi (JIRA), 6(7), 1-16.

Andriana, D. (2014). Pengaruh intellectual capital terhadap kinerja keuangan perusahaan. Jurnal Riset Akuntansi dan Keuangan, 2(1), 251-260.

Barus, A. C. (2017). Analisis Faktor-Faktor Yang Mempengaruhi Non Performing Loan pada Bank Umum di Indonesia. Jurnal Wira Ekonomi Mikroskil: JWEM, 6(2), 113-122.

Dwi, D. A. (2012). Pengaruh intellectual capital terhadap return on asset (roa) perbankan. Nominal: Barometer Riset Akuntansi dan Manajemen, 1(1), 34-40.

Hermina, R., \& Suprianto, E. (2016). Analisis Pengaruh Car, Npl, Ldr, Dan Bopo Terhadap Profitabilitas (Roe) Pada Bank Umum Syariah (Studi Kasus Pada Bank Umum Syariah di BEI 2008-2012). Jurnal Akuntansi Indonesia, 3(2), 129-142.

Ismail, M. B. A. (2015). Akuntansi Bank: Teori dan Aplikasi dalam Rupiah. Prenada Media.

Mashita, F. (2014). Pengaruh Risiko Usaha Terhadap Return On Equity Pada Bank Umum Swasta Nasional Devisa. Doctoral Dissertation. STIE Perbanas Surabaya.

Saputri, S. F. H., \& Oetomo, H. W. (2016). Pengaruh Car, Bopo, Npl Dan Fdr Terhadap Roe Pada Bank Devisa. Jurnal Ilmu dan Riset Manajemen (JIRM), 5(5), 1-19.

Sawarjuwono, T., \& Kadir, A. P. (2003). Intellectual capital: Perlakuan, pengukuran dan pelaporan (sebuah library research). Jurnal akuntansi dan keuangan, 5(1), 35-57.

Sawir, A. (2004). Kebijakan Pendanaan dan Restrukturisasi Perusahaan. Jakarta: Gramedia.

Septiani, R., \& Lestari, P. V. (2016). Pengaruh NPL dan LDR terhadap Profitabilitas dengan CAR sebagai variabel mediasi pada PT BPR pasarraya kuta. E-Jurnal Manajemen Universitas Udayana, 5(1), 293-324.

Stewart, T. A. (1998). Modal Intelektual: Kekayaan Baru Organisasi. Jakarta: PT Elex Media Komputindo.

Ulum, I. (2008). Intellectual capital performance sektor perbankan di Indonesia. Jurnal Akuntansi dan Keuangan, 10(2), 77-84.

Wati, E. (2011). Analisis Pengaruh BOPO,NIM,GWM,LDR,PPAP,dan NPL Terhadap ROE pada Bank Go Public dan Non Go Public di Indonesia Periode Tahun 2007-2009. Tesis. Universitas Diponegoro.

Wijaya, N. (2012). Pengaruh Intellectual Capital terhadap kinerja keuangan dan nilai pasar perusahaan perbankan dengan metode Value Added Intellectual Coefficient. Jurnal Bisnis dan Akuntansi, 14(3), 157-180.

Zaharruddin, H. (2006). Menggali Potensi Wirausaha. Bekasi: CV Dian Anugrah Prakasa. 